\title{
3D Printing-A Cutting Edge Technology for Treating Post-Infarction Patients
}

\author{
Daniel Cernica ${ }^{1,2} \mathbb{C}^{-}$, Imre Benedek ${ }^{1,2}$, Stefania Polexa ${ }^{1,2, *}$, Cosmin Tolescu ${ }^{1,2}$ and Theodora Benedek ${ }^{1,2}$ \\ 1 Center of Advanced Research in Multimodal Cardiovascular Imaging, Cardio Med Medical Center, \\ 540124 Targu Mures, Romania; daniel.cernica@umfst.ro (D.C.); imrebenedek@umfst.ro (I.B.); \\ tolescu.cosmin@yahoo.com (C.T.); theodora.benedek@umfst.ro (T.B.) \\ 2 Cardiology Department, University of Medicine, Pharmacy, Sciences and Technologies "George Emil Palade", \\ 540142 Targu Mures, Romania \\ * Correspondence: polexa.stefania@gmail.com; Tel.: +40-755297238
}

Citation: Cernica, D.; Benedek, I.;

Polexa, S.; Tolescu, C.; Benedek, T. 3D Printing-A Cutting Edge Technology for Treating Post-Infarction Patients. Life 2021, 11, 910. https://doi.org/10.3390/ life11090910

Academic Editor: Adrian Neagu

Received: 5 July 2021

Accepted: 28 August 2021

Published: 1 September 2021

Publisher's Note: MDPI stays neutral with regard to jurisdictional claims in published maps and institutional affiliations.

Copyright: (C) 2021 by the authors Licensee MDPI, Basel, Switzerland. This article is an open access article distributed under the terms and conditions of the Creative Commons Attribution (CC BY) license (https:/ / creativecommons.org/licenses/by/ $4.0 /)$.

\begin{abstract}
The increasing complexity of cardiovascular interventions requires advanced peri-procedural imaging and tailored treatment. Three-dimensional printing technology represents one of the most significant advances in the field of cardiac imaging, interventional cardiology or cardiovascular surgery. Patient-specific models may provide substantial information on intervention planning in complex cardiovascular diseases, and volumetric medical imaging from CT or MRI can be translated into patient-specific 3D models using advanced post-processing applications. 3D printing and additive manufacturing have a great variety of clinical applications targeting anatomy, implants and devices, assisting optimal interventional treatment and post-interventional evaluation. Although the 3D printing technology still lacks scientific evidence, its benefits have been shown in structural heart diseases as well as for treatment of complex arrhythmias and corrective surgery interventions. Recent development has enabled transformation of conventional 3D printing into complex 3D functional living tissues contributing to regenerative medicine through engineered bionic materials such hydrogels, cell suspensions or matrix components. This review aims to present the most recent clinical applications of 3D printing in cardiovascular medicine, highlighting also the potential for future development of this revolutionary technology in the medical field.
\end{abstract}

Keywords: 3D printing; additive manufacturing; anatomic model; regenerative cardiology; interventional cardiology

\section{3D Printing in Cardiology-Introduction}

Although three-dimensional printing has been commonly used in commercial fields in the last decade, the development of this new technology in medical field is still limited to several disciplines such as orthopedics, neurosurgery, maxillofacial surgery and cardiology $[1,2]$. In the cardiovascular field, besides research applications, 3D printing has been used for advanced visualization, improved diagnostic workflow, therapy guidance, simulation of minimally invasive and surgical procedures, and improvement of patient-physician communication [3-9].

The recent emergence of complex renderings of cardiac magnetic resonance (cMRI), cardiac computed tomography (CCT) and echo imagery have improved the visualization of pathologies, but lack in tactile experience and in three-dimensional complex visualization $[10,11]$. Conventional imaging techniques, such as CCT and cMRI, are mandatory to plan a complex intervention in patients with abnormal cardiac anatomy. However, they may provide limited spatial orientation in specific cases, giving that classic 3D renderings are displayed on a 2D screen. 3D printing technology can offer supplementary anatomic details to aid in pre-interventional planning, especially in cases characterized by complex 3D spatial relationships $[12,13]$. 


\section{3D Printing in Medical Applications-Basic Concepts and Technology}

The development of a patient-specific prototype of 3D anatomical models starts with the acquisition of the clinical images from volumetric imaging data, converted then to a 3D digital format and finally to a physically printed model $[14,15]$. Basic imaging dataset may be obtained from cardiac MRI (cMRI), cardiac CT, transesophageal echocardiography (TEE), trans-thoracic echocardiography or conventional angiography $[5,16]$. These image datasets are exported in DICOM (Digital Imaging and Communication in Medicine) standard format. Contrast-enhanced CT images are preferable for 3D digital reconstruction because of their superior spatial resolution, thin slices $(0.625 \mathrm{~mm})$, wide field of view, multidimensional reconstruction capabilities and differentiation of soft tissue from bone or calcified structures. These images are particularly well suited for replicating cardiac chambers, large cardiac vessels, heart valves, and sub-valvular apparatus morphologies. As an alternative, cMRI provides good spatial and temporal resolution and enables noninvasive visualization of complex cardiac structures as well as quantitative assessment of flow features. In fact, cMRI has been widely used to assess and characterize congenital cardiac defects and to generate 3D-printed cardiovascular replicas with congenital defects. Three-dimensional TEE captures the motion of dynamic anatomical structures such as heart valve leaflets and sub-valvular apparatus elements; this allows the clinical team to select and assess the imaging time window of greatest interest [17-20]. Similarly, any 3D conventional angiographic modality (CT angiography, cMRI and rotational angiography) offers high quality imaging datasets to fabricate an endovascular model, for planning and simulation of endovascular intervention.

3D printing workflow includes several steps, starting with acquisition of image data using of the previous mentioned imaging technologies (Figure 1). The next workflow step is image segmentation and post-processing to generate a typical digital format, namely STL or Standard Tessellation Language. Although several digital file formats are available, 3D printing model data is most commonly stored in STL format. For 3D printing technology, STL file format is the corresponding to DICOM format for conventional imaging. The STL file will be further post-processed using a computer-aided design (CAD) software system, which will complete the ultimate adjustments of the STL file before rapid prototyping. The final 3D model dataset is subsequently delivered to the 3D printer workstation to build the final physical models.

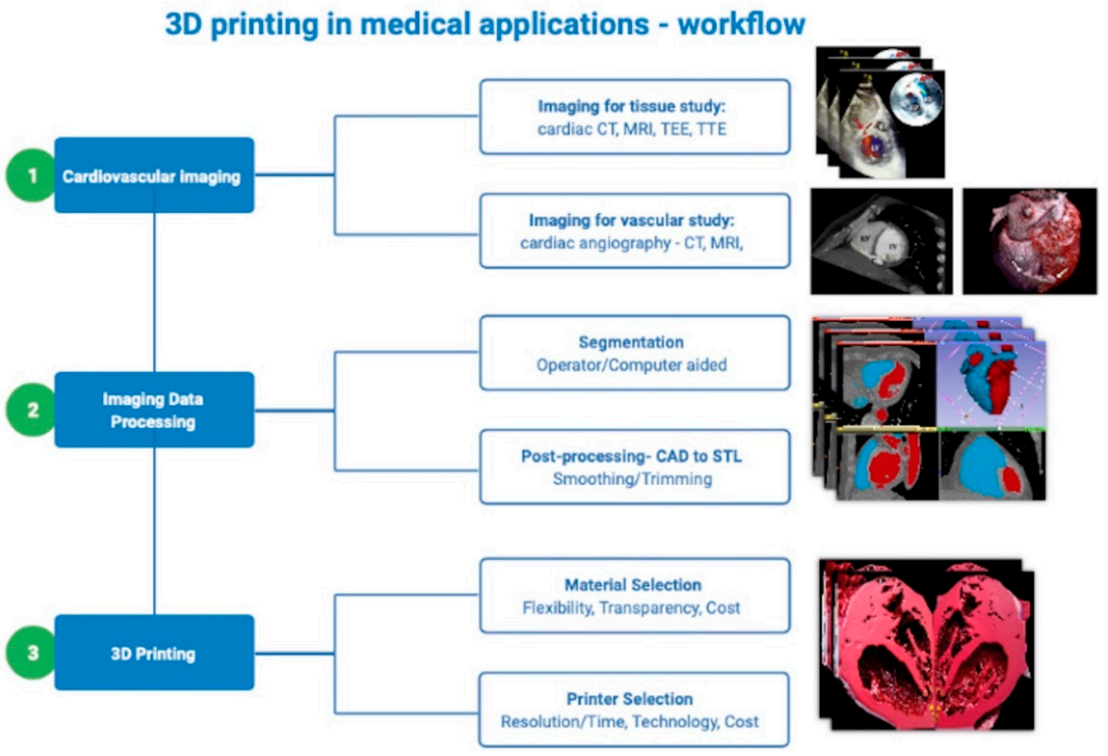

Figure 1. Cardiac 3D printing workflow.

Usually, the unstable parts are printed with dedicated support platform to give desired position in space. In terms of time span of a fabricated 3D model depends mainly on the 
phantom size, structural complexity of the anatomical model and resolution/speed of the selected printer. A normal adult cardiac model may take $24 \mathrm{~h}$ to achieve the complete process. At the final phase, the 3D stereo-lithographic model often includes a subsidiary material for support purposes, which requires removal either by operator or by automated machine spreading special solutions to achieve a clean model. Once this stage is completed, and the extra-support material has been removed, the ultimate 3D anatomic model is exposed and ready to be used [2].

Printing technologies can be classified into four main categories (Figure 2):

- $\quad$ Printing by using the polymerization method which includes stereolithography and digital light processing; it consists of a laser beam directed to a selected resin material to cure layer by layer [21]; phantoms printed with this technique generally have predictable mechanical properties (isotropic); this method can be used to mimic soft and hard tissues or to fabricate complex anatomical parts, including cardiac valves; the major advantage of this technique consists in the possibility to print complex structures with refined surfaces; however, this method requires higher cost for the used materials and printing machines [22,23].

- $\quad$ Powder-based printing includes selective laser sintering or melting and consist of focal heating beam to fuse the selected powdered materials [24]; materials compatible with this method range from plastic powder to ceramics and metal alloys, which gives it a major advantage; nevertheless, it is considered the most expensive method due to increased costs related to the mechanical parts of the printing system and print materials [25].

- $\quad$ Printing by using the droplet method requires multi-jet modeling with wax or trough laser beam induced forward transfer, which is commonly used to deploy photo-curable resins into layers [26]; the technique usually uses photo-polymer bio-resins to fabricate scaffolds for tissue development; the advantage consists of an augmented printing precision regardless of the model complexity and dimensions; however, it requires an extended time frame for model prototyping [27];

- The extrusion printing method includes a fused deposition and direct ink writing modeling, by using a thermo-sensitive plastic or ink materials, which are delivered through a special printhead, layer by layer on a dedicated support area [28]; the use of thermoplastic ink or hydrogels facilitates the fabrication of anisotropic models with increased density, that are able to resist high loads and increased strain; despite having a lower precision, this method uses the lowest costs in terms of materials and printing machines [29].

\section{Types of 3D printer technology}

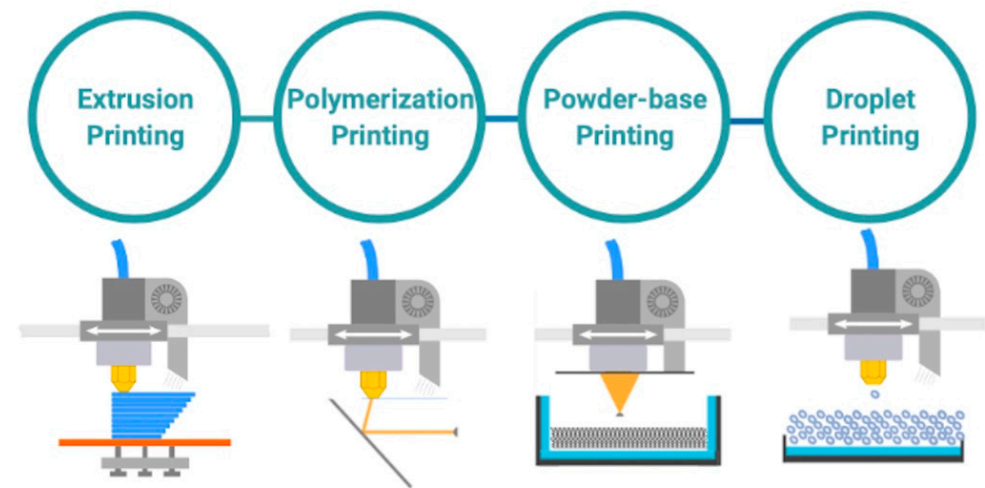

Figure 2. Types of 3D printer technology. 


\section{Selection of Materials for 3D Printing}

Material selection for 3D printing depends on the processing technique and the main field of activity in which the models are used. The variety of materials ranges from rigid to flexible, and also complex mixtures for combined properties.

\subsection{Rigid Materials}

Rigid materials are used mostly in pre-interventional planning models, which have been demonstrated to improve the spatial and structural understanding. The most commonly used printing materials are acrylonitrile butadiene styrene with fused filament modeling; this is considered as the most cost-effective material in the field of rapid prototyping. Moreover, the droplet method with thermoset materials has been used to fabricate appropriate devices for patient-specific models for simulation of flow resistances, with no model fractures, regardless of the fluid flow profiles. Metals such as titanium mostly used for printing implantable devices, due to its low weight, biocompatibility and sterilization adequacy [30].

\subsection{Flexible Materials}

By using flexible materials, printed models can attain various real-life haptic characteristics. This facilitates prototyping of 3D models with a wide range of flexibility and physical strength. For instance, a flexible material frequently used is thermoplastic polyurethane (TPU) which is an elastomeric resin, with a very high elasticity, flexibility and durability. This material frequently used in powder-based techniques can reproduce a wide variety of organs, tissues and vessels, thus allowing surgical and interventional simulations [31]. Similarly, the droplet-based process allows manufacture of flexible models, with TPU elastomers, which have a high UV resistance and resilience after deformation. Therefore, TPU models are suitable for incisions and suturing training. Another material with similar properties includes the flexible filament, which is suitable for 3D printing with the use of the extrusion process, with the advantage of being cost-efficient [32].

\subsection{Printing with Multiple Materials}

Multi-material compounds represent the future development of rapid prototyping models, that may be used to achieve realistic characteristics such as elastic and biological compatibilities. Three-dimensional printing by using fibers that appropriately regulate the mechanical performance of the physical model is currently under development [33].

\section{Clinical Applications of 3D Printing in Cardiology}

The main applications of 3D printing in cardiology being experimented in present are illustrated in Figure 3.

\section{Applications of 3D printing in cardiology}

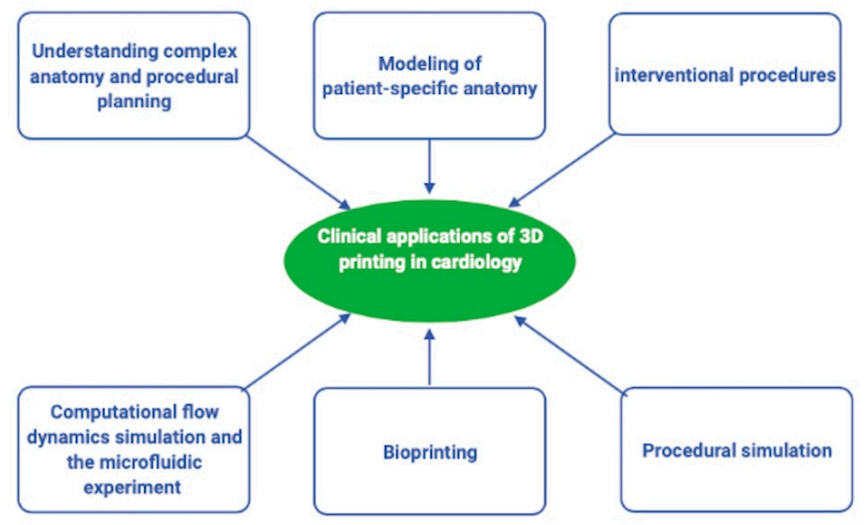

Figure 3. The main applications of 3D printing in cardiology. 


\section{3D Printing to Understand Complex Anatomy and Procedural Planning}

Stereolithography increases the stage of comprehensibility, especially in rare congenital heart disease or in post-myocardial mechanical complication, as each patient has specific cardiovascular anatomy and encompassing structures [17,34]. Congenital heart diseases imply a multitude of cardiovascular structures in a complex and unique pattern; Therefore, 3D-printed models have been shown to improve pre-procedural judgement and technical planning in these cases $[35,36]$. Printed phantoms have high resolution, with precise and smooth surfaces. It has been demonstrated by Valverde et al. that the pre-procedural approach was preserved after evaluation of the 3D model in $96.7 \%$ of the cases, while $96 \%$ of surgeons agreed that rapid prototyping models improved comprehensive status and technical planning [37]. Zhao et al. studied 25 patients with double outlet right ventricle and demonstrated that procedural times associated with cardiopulmonary bypass and cross-clamp were improved by pre-procedural 3D-printed model aid [38]. Olejník et al. studied rapid prototyping in tetralogy of Fallot with or without major arterio-pulmonary collateral arteries, showing that printed models of complex congenital heart defects facilitate pre-procedural decision and intraoperative orientation [39].

Schmauss et al. studied the role of surgery planning by rapid prototyping in patients with primary cardiac tumors, and demonstrated that $3 \mathrm{D}$ prototyping facilitates the diagnosis and therapeutic process by detailing the precise location and dissemination of the cardiac neoplasm into cardiac layers, especially when conventional imaging (CT, MRI or echocardiography) was unsatisfactory. They concluded that 3D printing enhanced both theoretic and intraoperative orientation for cardiac surgeons treating complex cardiovascular diseases [40-42]. Moreover, an experimental study conducted by Bateman and coworkers at the University of Minnesota's Academic Health Center proved the importance of rapid prototyping technology in decision making in complex congenital heart disease [43]. In addition, they demonstrated the benefits of 3D printing engineering in a case of conjoined children. The curative surgical procedure was directed secondary to creation of 3D models of both hearts revealing a previously unnoticed cardiac connection [44].

\section{3D Printing for Procedural Simulation}

The innovative potential of 3D printing includes facilitation of pre-procedural simulation for advanced intra-operative orientation and patient-specific tailored approach. Several experimental trials tried to assess whether rapid prototyping is applicable with simulation. Although the droplet printing process is expensive, it is capable to produce high precision 3D models. Additionally, it can use a multitude of polymer-based materials leading to fabricate models with variable density and flexibility to achieve real-like physical properties. Hazeveld et al. conducted a study to compare various 3D printing processes in terms of dimensional accuracy. They concluded that the highest dimensional precision method was the ink-jet technique [45]. For instance, Shiraishi et al. generated twelve 3D models by using both solid resin and flexible urethane materials, to simulate surgical and catheter intervention. The bio-models allowed better visual and tactile examination of anatomic specimen [46,47]. Motwani et coworkers described the utility of rapid prototyping models from CCT in several cases of aortic paravalvular leak. Giving a novel approach by transcatheter closure of paravalvular leak, 3D models allowed simulation of various treatment devices, with satisfactory outcomes [48]. Another application of modeling for procedural simulation was recently studied by Engelhardt and colleagues, who printed for the first time an integral mitral valve apparatus. Thus, cardiac surgeons could simulate various surgical techniques, such as annuloplasty, chordae implantation and leaflet-plasty. They concluded that 3D models were of superior quality and offered a high realism perspective by haptic interaction with surgical materials [49].

\section{3D Printing for Modeling of Patient-Specific Anatomy}

A common complication of atrial fibrillation is represented by thrombosis of the left atrial appendage. According to international guidelines, percutaneous closure of 
the left atrial appendage is a treatment strategy adopted in selected patients, in order to prevent systemic embolization of such thrombus. Selection of the best dimensions and closure devices may be difficult in some cases with difficult anatomy. The powder-based printing method is widely utilized in producing bio-compatible implants. Considering the availability of a wide range of compatible materials, such as titanium alloy, zinc alloy, and cobalt-chrome alloy, and their mechanical characteristics and biocompatibility, this technique is the most promising in fabricating implants in cardiovascular surgery or percutaneous cardiovascular intervention field. This method is also the most appropriate to fabricate sterilizable devices [50]. In a recent study, Fan et al. emphasized the incremental outcome provided by association of TEE imaging and 3D printing technology in patients selected for left atrial appendage closure. They analyzed 72 patients with LAA occlusion device, comparing a group with TEE imaging-guided procedure with a group with $3 \mathrm{D}$ printed guided procedure. The study results showed that the use of stereolithographic models improved the procedural outcome in terms of safety and efficacy, lowering the procedural duration, complications and MACE at three years follow up [51]. The innovative potential of fabricated 3D-printed models was validated in a similar study by Lazkani et al., who studied the role of rapid prototyping models in the surgical management of patients with ventricular septal defect following a myocardial infarction. They described the first case of a 3D-printed cardiac model from cardiac CT imaging used to guide a percutaneous closure of VSD, and reported that 3D printing technology provides the advantage to in-vitro assess the compatibility with multiple devices in terms of size and occluder type, at the same time improving the operator perspective and orientation among cardiac structures in fabricated model [52].

\section{3D Printing to Assist Interventional Procedures}

Lodziński et al. described the role of 3D printing to assist complex electrophysiology procedures, in a case referred for ventricular tachycardia ablation in whom aberrant anatomic relationship between right ventricular outflow tract and right coronary artery was identified. A rapid prototyping model may be generated based on cardiac CT imaging, providing detailed information about anatomic relationship between cardiac structures, thus facilitating ablation of cardiac arrhythmia [53-56]. For instance, according to Rossi et al. work, for the rapid prototyping of the atria are usually used thermoplastic materials or rigid resin with extrusion process or powder-based process in order to obtain the most accurate anatomical model to merge with electrophysiology mapping system [57]. Yeazel et al. studied a novel approach in terms of percutaneous coronary stenting procedures, using 3Dprinted scaffolds based on bio-resorbable materials and shape memory structure pattern. They described several advantages of 3D printing in interventional cardiology, such as tailoring patient-personalized production of devices or improving the management of stent migration or other complications [58,59]. Table 1 summarizes the most relevant studies published about the role of 3D printing technology for assisting cardiovascular interventions, together with their main results.

Table 1. 3D printing applications in cardiac interventions.

\begin{tabular}{|c|c|c|c|c|c|c|c|c|}
\hline First Author & $\begin{array}{c}\text { Clinical } \\
\text { Application }\end{array}$ & $\begin{array}{l}\text { Imaging } \\
\text { Modality }\end{array}$ & $\begin{array}{c}\text { 3D-Printed } \\
\text { Material }\end{array}$ & $\begin{array}{l}\text { Printing } \\
\text { Method }\end{array}$ & Year & Country & Objective & Results \\
\hline $\begin{array}{l}\text { Lazkani M. } \\
\text { et al. [52] }\end{array}$ & $\begin{array}{c}\text { Postinfarct } \\
\text { VSD treatment }\end{array}$ & $\begin{array}{l}\text { Computed } \\
\text { tomography } \\
\text { Angiography }\end{array}$ & $\begin{array}{c}\text { Gypsum- } \\
\text { cyanoacrylate }\end{array}$ & Stereolithography & 2015 & USA & $\begin{array}{l}\text { To evaluate the role } \\
\text { of 3D-printed } \\
\text { occluder in guided } \\
\text { percutaneous } \\
\text { treatment of } \\
\text { complex PIVSD }\end{array}$ & $\begin{array}{l}\text { 3D printing model } \\
\text { guide size and } \\
\text { choice of septal } \\
\text { occluder with no } \\
\text { residual shunt }\end{array}$ \\
\hline
\end{tabular}


Table 1. Cont.

\begin{tabular}{|c|c|c|c|c|c|c|c|c|}
\hline First Author & $\begin{array}{c}\text { Clinical } \\
\text { Application }\end{array}$ & $\begin{array}{l}\text { Imaging } \\
\text { Modality }\end{array}$ & $\begin{array}{l}\text { 3D-Printed } \\
\text { Material }\end{array}$ & $\begin{array}{l}\text { Printing } \\
\text { Method }\end{array}$ & Year & Country & Objective & Results \\
\hline $\begin{array}{l}\text { Modi B. } \\
\text { et al. [60] }\end{array}$ & $\begin{array}{c}\text { Assess } \\
\text { Coronary } \\
\text { Artery Disease }\end{array}$ & $\begin{array}{c}\text { Coronary } \\
\text { angiogram }\end{array}$ & Photopolymer & Ink Jet & 2018 & $\begin{array}{l}\text { United } \\
\text { King- } \\
\text { dom }\end{array}$ & $\begin{array}{l}\text { Three-dimensional- } \\
\text { printing to } \\
\text { characterize serial } \\
\text { stenosis interplay } \\
\text { in vitro }\end{array}$ & $\begin{array}{c}\text { Generated and } \\
\text { tested a } \\
\text { mathematical } \\
\text { equation to } \\
\text { improve estimation } \\
\text { of the true } \\
\text { physiological } \\
\text { impact of each } \\
\text { stenosis, using } \\
\text { measurements } \\
\text { from a routine } \\
\text { pressure- } \\
\text { wire study }\end{array}$ \\
\hline $\begin{array}{l}\text { Oliveira- } \\
\text { Santos M. } \\
\text { et al. [61] }\end{array}$ & $\begin{array}{l}\text { Simulation } \\
\text { percutaneous } \\
\text { coronary } \\
\text { intervention }\end{array}$ & $\begin{array}{l}\text { Coronary } \\
\text { angiogram }\end{array}$ & $\begin{array}{c}\text { Hybrid } \\
\text { flexible filled } \\
\text { with fluid }\end{array}$ & Stereolithography & 2018 & Portugal & $\begin{array}{l}\text { Patient-specific } \\
\text { simulation of } \\
\text { percutaneous } \\
\text { coronary } \\
\text { intervention }\end{array}$ & $\begin{array}{l}\text { Patient-specific } \\
\text { simulation is } \\
\text { feasible to guide } \\
\text { the treatment } \\
\text { strategy of complex } \\
\text { coronary artery } \\
\text { disease (e.g., } \\
\text { treating a critical } \\
\text { ostial Cx stenosis) }\end{array}$ \\
\hline $\begin{array}{l}\text { Wang H. } \\
\text { et al. [62] }\end{array}$ & $\begin{array}{l}\text { Optimized } \\
\text { stent } \\
\text { implantation } \\
\text { strategy }\end{array}$ & $\begin{array}{l}\text { Coronary } \\
\text { angiogram }\end{array}$ & $\begin{array}{l}\text { Polydimethy- } \\
\text { lsiloxane }\end{array}$ & Wax Jet & 2015 & China & $\begin{array}{l}\text { Optimized stent } \\
\text { position in } \\
\text { microfluidic } \\
\text { settings through } \\
\text { 3D printing } \\
\text { technology }\end{array}$ & $\begin{array}{l}\text { Microfluidic model } \\
\text { has demonstrated } \\
\text { to be a feasible and } \\
\text { novel approach for } \\
\text { hemodynamic } \\
\text { study of } \\
\text { coronary disease }\end{array}$ \\
\hline $\begin{array}{l}\text { Velasco M. } \\
\text { et al. [63] }\end{array}$ & $\begin{array}{l}\text { Diagnosis and } \\
\text { interventional } \\
\text { planning of } \\
\text { coronary } \\
\text { artery fistulae }\end{array}$ & $\begin{array}{l}\text { Computed } \\
\text { tomography } \\
\text { and cardiac } \\
\text { magnetic } \\
\text { resonance }\end{array}$ & $\begin{array}{c}\text { Polyjet } \\
\text { photopolymer }\end{array}$ & Polyjet & 2017 & $\begin{array}{l}\text { United } \\
\text { King- } \\
\text { dom }\end{array}$ & $\begin{array}{l}\text { To evaluate the } \\
\text { 3D-printed models } \\
\text { contribution to the } \\
\text { diagnosis and } \\
\text { interventional } \\
\text { planning of } \\
\text { coronary artery } \\
\text { fistulae }\end{array}$ & $\begin{array}{l}\text { Improvement in } \\
\text { selection of the } \\
\text { correct equipment } \\
\text { and in reduction of } \\
\text { procedure times }\end{array}$ \\
\hline $\begin{array}{c}\text { Sedaghat A. } \\
\text { et al. [64] }\end{array}$ & $\begin{array}{l}\text { Percutaneous } \\
\text { treatment of } \\
\text { coronary } \\
\text { artery } \\
\text { aneurysm }\end{array}$ & $\begin{array}{l}\text { Computed } \\
\text { tomography } \\
\text { Angiography }\end{array}$ & Silicone & Stereolithography & 2018 & Germany & $\begin{array}{l}\text { To investigate a } \\
\text { multimodal } \\
\text { preprocedural } \\
\text { planning in } \\
\text { percutaneous } \\
\text { coronary aneurysm } \\
\text { treatment }\end{array}$ & $\begin{array}{l}\text { Confirm the benefit } \\
\text { of ex vivo } \\
\text { 3D-printed model } \\
\text { in interventional } \\
\text { treatment of an } \\
\text { extensive coronary } \\
\text { aneurysm }\end{array}$ \\
\hline $\begin{array}{l}\text { Mohamed E. } \\
\text { et al. [65] }\end{array}$ & $\begin{array}{l}\text { Percutaneous } \\
\text { treatment of } \\
\text { left ventricle } \\
\text { pseudoa- } \\
\text { neurysm }\end{array}$ & $\begin{array}{l}\text { Computed } \\
\text { tomography } \\
\text { Angiography }\end{array}$ & Clear resin & Stereolithography & 2019 & USA & $\begin{array}{l}\text { To investigate the } \\
\text { role of 3D model in } \\
\text { complications of } \\
\text { myocardial } \\
\text { infarction }\end{array}$ & $\begin{array}{l}\text { Improve the } \\
\text { accuracy to } \\
\text { cannulate the } \\
\text { aneurysm, select } \\
\text { the appropriate } \\
\text { sheath/catheter } \\
\text { shape and } \\
\text { determine the most } \\
\text { suitable occluder } \\
\text { device type } \\
\text { and size }\end{array}$ \\
\hline $\begin{array}{l}\text { Bompotis G. } \\
\text { et al. [66] }\end{array}$ & $\begin{array}{l}\text { Transcatheter } \\
\text { aortic valve } \\
\text { implantation }\end{array}$ & $\begin{array}{l}\text { Computed } \\
\text { tomography } \\
\text { aortography }\end{array}$ & Clear resin & Stereolithography & 2019 & Greece & $\begin{array}{l}\text { To investigate the } \\
\text { role of 3D model in } \\
\text { transcatheter valve } \\
\text { implantation }\end{array}$ & $\begin{array}{c}\text { It was } \\
\text { demonstrated to be } \\
\text { a significant tool } \\
\text { for the optimal } \\
\text { sizing and } \\
\text { positioning of the } \\
\text { transcatheter } \\
\text { implantation of the } \\
\text { bioprosthetic } \\
\text { valves and the } \\
\text { reduction of the } \\
\text { para- valvular leak }\end{array}$ \\
\hline $\begin{array}{c}\text { Baribeau Y. } \\
\text { et al. [67] }\end{array}$ & $\begin{array}{l}\text { Complex } \\
\text { procedures on } \\
\text { patient- } \\
\text { specific } \\
\text { models }\end{array}$ & $\begin{array}{c}\text { Transesophageal } \\
\text { Echocardio- } \\
\text { graphic }\end{array}$ & Clear resin & Stereolithography & 2019 & USA & $\begin{array}{c}\text { Procedural } \\
\text { simulation that use } \\
\text { a pulsatile } \\
\text { left-sided heart } \\
\text { printed model }\end{array}$ & $\begin{array}{l}\text { Provided a better } \\
\text { understanding of } \\
\text { the anatomy and } \\
\text { assessing the effect } \\
\text { of interventions }\end{array}$ \\
\hline
\end{tabular}


Table 1. Cont.

\begin{tabular}{|c|c|c|c|c|c|c|c|c|}
\hline First Author & $\begin{array}{c}\text { Clinical } \\
\text { Application }\end{array}$ & $\begin{array}{l}\text { Imaging } \\
\text { Modality }\end{array}$ & $\begin{array}{c}\text { 3D-Printed } \\
\text { Material }\end{array}$ & $\begin{array}{l}\text { Printing } \\
\text { Method }\end{array}$ & Year & Country & Objective & Results \\
\hline Iriarta X. et al. [68] & $\begin{array}{l}\text { Percutaneous } \\
\text { appendage } \\
\text { closure }\end{array}$ & $\begin{array}{l}\text { Computed } \\
\text { tomography } \\
\text { angiography }\end{array}$ & $\begin{array}{c}\text { Rubber-like } \\
\text { material }\end{array}$ & Stereolithography & 2018 & France & $\begin{array}{l}\text { To study the role of } \\
\text { cardiac } \\
\text { three-dimensional } \\
\text { printing in } \\
\text { percutaneous } \\
\text { appendage closure }\end{array}$ & $\begin{array}{l}\text { 3D model allow } \\
\text { testing of several } \\
\text { designs of } \\
\text { prosthesis to better } \\
\text { choose the optimal } \\
\text { shape and size of } \\
\text { the patient-specific } \\
\text { prothesis to } \\
\text { prevent procedural } \\
\text { complications }\end{array}$ \\
\hline $\begin{array}{l}\text { Lodziński P. } \\
\text { et al. [69] }\end{array}$ & $\begin{array}{l}\text { Ventricular } \\
\text { tachycardia } \\
\text { ablation }\end{array}$ & $\begin{array}{l}\text { Computed } \\
\text { tomography } \\
\text { angiography }\end{array}$ & $\begin{array}{c}\text { Gypsum- } \\
\text { cyanoacrylate }\end{array}$ & Stereolithography & 2017 & Poland & $\begin{array}{l}\text { To investigate the } \\
\text { role of 3D model in } \\
\text { complex } \\
\text { tachycardia } \\
\text { treatment }\end{array}$ & $\begin{array}{l}\text { Improve spatial } \\
\text { orientation in } \\
\text { patients with } \\
\text { complex anatomy } \\
\text { and provide a } \\
\text { novel technology } \\
\text { of mapping in } \\
\text { ablation } \\
\text { procedures }\end{array}$ \\
\hline
\end{tabular}

\section{3D Printing for Computational Flow Dynamics Simulation}

The main use of computational flow dynamics (CFD) simulations is to better comprehend of the relationship between vessels, hemodynamics and development and progression of cardiovascular disease. Experiments for 3D printing and CFD simulation require the combined use of rapid prototyping models with a flow measurement system by MRI or particle image velocimetry [70]. Zelicourt et al. studied three-dimensional replication of a complex computational fluid dynamics system in a printed model for total cavopulmonary connection. The model was printed by using the stereolithographic technique with thermo-plastic resin, completed with a transparent acrylic paint. The study concluded that their model was appropriate for CFD dynamics simulations on vascular and cardiac structures, although the limitation was an increased model rigidity. [71]. Maragiannis and coworkers studied anatomical and functional characteristics of severe aortic stenosis using patient-specific models from cardiac-computed tomography. They used 3D printers with multi-material system to reproduce various structural lesions of the aortic valve. Thus, by combining conventional cardiac imaging, computed aided processing and $3 \mathrm{D}$ printing of patient-specific models could represent a novel technique to assess anatomy and functional characteristics of valvular heart diseases [72,73]. Functional post-interventional follow-up using rapid prototyping was also studied. According to Qian et al., paravalvular leak after trans catheter aortic valve replacement may be better assessed by using 3D models from cardiac CT imaging, and a novel index was described for prediction of paravalvular leak. This index, namely the annular bulge index, is based on metamaterials to mimic integral properties of a biological valve in a $3 \mathrm{D}$ environment $[74,75]$.

\section{3D Printing for Bioprinting}

A novel landmark in rapid prototyping technology concerns bioprinting or tissue engineering, which aims to provide a promising research opportunity. It consists of printing, layer by layer, a complex structure to mimic a real tissue structure. The most suitable technique is the droplet process with hydrogel materials. The laser printing technique has also been used in experimental studies, demonstrating a high spatial control of the cellular environment [76,77]. The main potential advantage of 3D bio-printed models concerns especially the field of regenerative medicine having also applicability in drug delivery or medical nanotechnology [18,78-80]. Table 2 summarizes the most relevant studies about 3D bioprinting and their applications in cardiology and their main outcomes.

Bio-fabrication of 3D models integrated with tissue specific cells that can be directly delivered on damaged tissue represents a unique potential solution for myocardial regeneration after a myocardial infarction. Molecular 3D bio-printing could represent the next generation in terms of personalized patient-specific medicine. This complex technology 
could facilitate interventions guided by specific biomarkers, in addition to tissue-based biomarkers. The novel paradigm of personalized medicine combines conventional anatomy imaging, functional assessing, physiology quantification, and also molecular diagnosis. Bio-printed models can determine specific molecular tagets for diagnosis and intervention, and molecular 3D printing may provide the boundary of future research, such as the development of imaging modalities with 3D printing technology, combined with genomics and molecular target labelling [81].

The most used systems in bioprinting are laser direct writing, inkjet extrusion, and cell electrospinning. Basara et al. produced a tissue engineering patch for patients with myocardial infarction, using a 3D-printed conductive titanium carbide integrated in a poly-etilenglycol hydrogel $[14,82]$. Their results showed that bio-printed human-induced pluripotent stem cells derived cardiomyocytes synchronous beating, in parallel with an incremental expression of cardiac genes, thus creating a physiologically-like environment [77,83-87]. Similarly, Izadifar et al. studied a 3D-printed hybrid cardiac patch enriched with human coronary artery endothelial cells, using a combination of 3D-printed carbon nanotubes and collagen. At 10 days of in-vitro incubation, a network of nanofilaments was observed with a size up to $50 \mathrm{~nm}$, with electrical and contractile improved activity. Moreover, stem cells presented a high level of proliferation and differentiation. Nowadays, the three-dimensional bioprinting represents a paramount in the scientific development. Though, it raises an ethical controversy about methods of rapid prototyping and cells or biomaterials manipulation. Specific approach and guidelines are needed to be designed in future [88-90].

Table 2. Applications of 3D bioprinting in cardiology.

\begin{tabular}{|c|c|c|c|c|c|c|c|}
\hline First Author & $\begin{array}{c}\text { Clinical } \\
\text { Application }\end{array}$ & $\begin{array}{c}\text { Supportive } \\
\text { Material }\end{array}$ & Printing Method & Year & Country & Objective & Results \\
\hline $\begin{array}{l}\text { Gozde B. } \\
\text { et al. [88] }\end{array}$ & $\begin{array}{l}\text { Conductive } \\
\text { composite in } \\
\text { treatment of } \\
\text { myocardial } \\
\text { infarction }\end{array}$ & $\begin{array}{l}\text { Titanium carbide } \\
\text { mxene }\end{array}$ & $\begin{array}{l}\text { Aerosol Jet } \\
\text { Printing }\end{array}$ & 2020 & USA & $\begin{array}{l}\text { To investigate cardiac } \\
\text { patches as conductive } \\
\text { myocardial tissue }\end{array}$ & $\begin{array}{l}\text { Increase of MYH7, } \\
\text { SERCA2, } \\
\text { TNNT2 expression and } \\
\text { conductive velocity }\end{array}$ \\
\hline $\begin{array}{l}\text { Izadifar M. } \\
\text { et al. [89] }\end{array}$ & $\begin{array}{l}\text { Intracoronary } \\
\text { hybrid cardiac } \\
\text { patch in ischemic } \\
\text { heart disease }\end{array}$ & $\begin{array}{l}\text { Methacrylated } \\
\text { collagen }\end{array}$ & $\begin{array}{l}\text { UV-integrated } \\
\text { 3D-bioprinting- } \\
\text { hydrogel }\end{array}$ & 2017 & Canada & $\begin{array}{c}\text { To investigate } \\
\text { hydrogel carboxyl } \\
\text { functionalized carbon } \\
\text { nanotubes }\end{array}$ & $\begin{array}{c}\text { 3D-bioprinted nanotubes } \\
\text { presented significant } \\
\text { cellular proliferation, } \\
\text { migration and } \\
\text { differentiation } \\
\text { incubation time }\end{array}$ \\
\hline $\begin{array}{l}\text { Yeung E. } \\
\text { et al. [91] }\end{array}$ & $\begin{array}{l}\text { Regenerative } \\
\text { patch in heart } \\
\text { failure }\end{array}$ & Biomaterial-free & $\begin{array}{l}\text { Monolayer } \\
\text { bioprint on } \\
\text { needle array }\end{array}$ & 2019 & USA & $\begin{array}{c}\text { To investigate } \\
\text { bioprinted patch } \\
\text { in vivo scaffold free }\end{array}$ & $\begin{array}{l}\text { Increased the average } \\
\text { vessel counts patch group; } \\
\text { the scar area in the cardiac } \\
\text { patch group was } \\
\text { significantly smaller }\end{array}$ \\
\hline $\begin{array}{l}\text { Gaetani R. } \\
\text { et al. [92] }\end{array}$ & $\begin{array}{c}\text { Role of } \\
\text { epicardial tissue } \\
\text { in myocardial } \\
\text { infarction }\end{array}$ & $\begin{array}{c}\text { Gelatin and } \\
\text { hyaluronic acid } \\
\text { matrix (hystem } \\
\text { matrix) }\end{array}$ & $\begin{array}{l}\text { Bioscaffolder-ink } \\
\text { jet }\end{array}$ & 2015 & Netherlands & $\begin{array}{l}\text { To evaluate the role of } \\
\text { a 3D-printed patch } \\
\text { composed of human } \\
\text { cardiac-derived } \\
\text { progenitor cells in a } \\
\text { hyaluronic } \\
\text { acid/gelatin matrix }\end{array}$ & $\begin{array}{l}\text { Reduction in remodeling } \\
\text { and preservation of } \\
\text { cardiac performance and } \\
\text { increase in cardiac and } \\
\text { vascular differentiation at } \\
\text { four weeks follow up }\end{array}$ \\
\hline $\begin{array}{l}\text { Jang J. } \\
\text { et al. [93] }\end{array}$ & $\begin{array}{l}\text { Treatment of } \\
\text { ischemic heart } \\
\text { disease }\end{array}$ & $\begin{array}{l}\text { Decellularized } \\
\text { extracellular } \\
\text { matrix bioinks }\end{array}$ & Bio-ink printing & 2016 & Korea & $\begin{array}{l}\text { To evaluate 3D } \\
\text { pre-vascularized stem } \\
\text { cell patch of cardiac } \\
\text { remodeling and } \\
\text { fibrosis, and } \\
\text { promotional effects of } \\
\text { cardiomyogenesis } \\
\text { and } \\
\text { neovascularization }\end{array}$ & $\begin{array}{l}\text { Reduction of cardiac } \\
\text { remodeling and fibrosis by } \\
\text { modulating inflammation, } \\
\text { apoptosis, and cardiac } \\
\text { metabolism; increasing of } \\
\text { neovascularization }\end{array}$ \\
\hline $\begin{array}{l}\text { Gao L. } \\
\text { et al. [94] }\end{array}$ & $\begin{array}{l}\text { Treatment of } \\
\text { ischemic heart } \\
\text { disease }\end{array}$ & $\begin{array}{l}\text { Photoactive } \\
\text { gelatin polymer }\end{array}$ & $\begin{array}{l}\text { Multiphoton- } \\
\text { excited } \\
\text { photochemistry } \\
\text { printing }\end{array}$ & 2018 & USA & $\begin{array}{l}\text { To evaluate } \\
\text { bioprinted scaffold } \\
\text { with cardiomyocytes, } \\
\text { smooth muscle cells, } \\
\text { and endothelial cells } \\
\text { in a murine model of } \\
\text { myocardial infarction }\end{array}$ & $\begin{array}{c}\text { The scaffold promoted cell } \\
\text { viability and } \\
\text { electromechanical } \\
\text { coupling in vitro, high } \\
\text { levels of cell engraftment, } \\
\text { as well as significant } \\
\text { improvements in cardiac } \\
\text { function, infarct size, } \\
\text { apoptosis, vascularity, and } \\
\text { cell proliferation in a } \\
\text { murine MI model }\end{array}$ \\
\hline
\end{tabular}


Table 2. Cont.

\begin{tabular}{|c|c|c|c|c|c|c|c|}
\hline First Author & $\begin{array}{c}\text { Clinical } \\
\text { Application }\end{array}$ & $\begin{array}{c}\text { Supportive } \\
\text { Material }\end{array}$ & Printing Method & Year & Country & Objective & Results \\
\hline $\begin{array}{l}\text { Wang Z. } \\
\text { et al. [95] }\end{array}$ & $\begin{array}{l}\text { Heart failure } \\
\text { treatment }\end{array}$ & $\begin{array}{l}\text { Fibrin-based } \\
\text { composite } \\
\text { hydrogel }\end{array}$ & Bioink hydrogel & 2018 & USA & $\begin{array}{l}\text { Develop a functional } \\
\text { cardiac tissue in heart } \\
\text { failure }\end{array}$ & $\begin{array}{l}\text { Bioprinted cardiac tissue } \\
\text { is not structural and } \\
\text { functional like native } \\
\text { tissue after printing, } \\
\text { instead the tissues are } \\
\text { matured after three to four } \\
\text { weeks in culture }\end{array}$ \\
\hline $\begin{array}{l}\text { Park S. } \\
\text { et al. [96] }\end{array}$ & $\begin{array}{l}\text { Treating } \\
\text { coronary } \\
\text { thrombosis }\end{array}$ & $\begin{array}{l}\text { Polycaprolactone } \\
\text { mixed with } \\
\text { poly-lactide-co- } \\
\text { glycolide and } \\
\text { polyethylene } \\
\text { glycol }\end{array}$ & $\begin{array}{l}\text { Rotational 3D } \\
\text { printing }\end{array}$ & 2014 & Korea & $\begin{array}{c}\text { To evaluate feasibility } \\
\text { of 3D-printed } \\
\text { biocompatible and } \\
\text { biodegradable stent }\end{array}$ & $\begin{array}{l}\text { It showed a reduction of } \\
\text { neointimal hyperplasia, } \\
\text { the inflammatory cells } \\
\text { and fibrin infiltrated } \\
\text { around the struts }\end{array}$ \\
\hline
\end{tabular}

\section{Future Directions}

Three-dimensional printing has been introduced in clinical practice, not only for research purposes. This method has the potential to trigger a paradigm shift towards a personalized approach in diagnostics and therapeutic management of various medical conditions. Three-dimensional models may also be used in a variety of cardiovascular applications, such as customizing tailored-patient devices, organ tissues or producing complex drugs delivery systems on-demand [97]. The most promising application in this field is the bioprinting of complex tissues and viable implants. The future steps could be made towards stem cells manipulation for growing specific tissues, that can be used as replacement or corrective tissues [98]. In situ three-dimensional printing is another expected advance, which consists of fabricating specific tissues in real time during a surgical intervention [77].

\section{Conclusions}

Three-dimensional printing has a great potential to revolutionize personalized medicine. This technology may be used for advanced diagnostic and treatment applications in various medical applications, such as peri-operative planning for complex congenital heart diseases, guidance of interventional procedures or procedural simulation. Recent experimental studies are directed to emerging applications of 3D printing, including bio-printing and molecular printing, which will allow a better approach of various cardiac pathologies. However, in the long term perspective, more experimental studies are needed to generate solid evidence regarding the benefits of this novel technology, as well as its feasibility in clinical practice.

Author Contributions: Conceptualization, T.B., I.B. and D.C.; investigation, S.P., C.T. and D.C.; resources, T.B., D.C. and I.B.; data curation, D.C., T.B., S.P. and I.B.; writing-original draft preparation, D.C., T.B. and I.B.; writing—review and editing, S.P., D.C., T.B.; visualization, D.C., C.T. and T.B.; supervision, T.B. and I.B. All authors have read and agreed to the published version of the manuscript.

Funding: This research received no external funding.

Institutional Review Board Statement: Not applicable.

Informed Consent Statement: Not applicable.

Data Availability Statement: Not applicable.

Acknowledgments: Nothing to declare.

Conflicts of Interest: The authors declare no conflict of interest.

\section{References}

1. Farooqi, K.; Cooper, C. 3D Printing and Heart Failure: The Present and the Future. JACC Heart Fail. 2019, 7, 132-142. [CrossRef]

2. Giannopoulos, A.A. Cardiothoracic applications of 3-dimensional printing. J. Thorac. Imaging 2016, 31, 253-272. [CrossRef] 
3. Kim, M.S.; Hansgen, A.R.; Carroll, J. Rapid prototyping: A new tool in understanding and treating structural heart disease. Circulation 2008, 117, 2388-2394. [CrossRef] [PubMed]

4. Ryan, J.R. A novel approach to neonatal management of tetralogy of Fallot, with pulmonary atresia, and multiple aortopulmonary collaterals. JACC Cardiovasc. Imaging 2015, 8, 103-104. [CrossRef]

5. Schmauss, D.; Haeberle, S. Three-dimensional printing in cardiac surgery and interventional cardiology: A single-centre experience. Eur. J. Cardiothorac. Surg. 2015, 47, 1044-1052. [CrossRef]

6. Pellegrino, P.L.; Fassini, G.; Di Biase, M. Left atrial appendage closure guided by 3D-printed cardiac reconstruction: Emerging directions and future trends. J. Cardiovasc. Electrophysiol. 2016, 27, 768-771. [CrossRef] [PubMed]

7. Yang, D.H. Myocardial 3-dimensional printing for septal myectomy guidance in a patient with obstructive hypertrophic cardiomyopathy. Circulation 2015, 132, 300-301. [CrossRef]

8. Mashari, A. Hemodynamic testing of patient-specific mitral valves using a pulse duplicator: A clinical application of threedimensional printing. J. Cardiothorac. Vasc. Anesth. 2016, 30, 1278-1285. [CrossRef]

9. Sulkin, M.S. Three-dimensional printing physiology laboratory technology. Am. J. Physiol. Heart Circ. Physiol. 2013, 305, H1569-H1573. [CrossRef]

10. Biglino, G. 3D-manufactured patient-specific models of congenital heart defects for communication in clinical practice: Feasibility and acceptability. BMJ Open 2015, 5, e007165. [CrossRef]

11. Costello, J. Incorporating three-dimensional printing into a simulation-based congenital heart disease and critical care training curriculum for resident physicians. Congenit. Heart Dis. 2015, 10, 185-190. [CrossRef]

12. Wurm, G.; Tomancok, B. Cerebrovascular stereolithographic biomodeling for aneurysm surgery. J. Neurosurg. 2004, 100, 139-145. [CrossRef]

13. Farooqi, K.M.; Nielsen, J.C. Use of 3-dimensional printing to demonstrate complex intracardiac relationships in double-outlet right ventricle for surgical planning. Circ. Cardiovasc. Imaging 2015, 8, e003043. [CrossRef] [PubMed]

14. Melchels, F.P.; Domingos, M.A. Additive manufacturing of tissues and organs. Prog. Polym. Sci. 2012, 37, 1079-1104. [CrossRef]

15. Parimi, M.; Buelter, J. Feasibility and validity of printing 3d heart models from rotational angiography. Pediatr. Cardiol. 2018, 39, 653-658. [CrossRef]

16. Mitsouras, D. Medical 3D printing for the radiologist. Radiographics 2015, 35, 1965-1988. [CrossRef] [PubMed]

17. Wang, D.D.; Gheewala, N. Three-Dimensional Printing for Planning of Structural Heart Interventions. Interv. Cardiol. Clin. 2018, 7, 415-423. [CrossRef]

18. Wang, K.; Wu, C. Dual-material 3D-printed metamaterials with tunable mechanical properties for patient-specific tissuemimicking phantoms. Addit. Manuf. 2016, 12, 31-37. [CrossRef]

19. Kim, G.B. Three-dimensional printing: Basic principles and applications in medicine and radiology. Korean J. Radiol. 2016, 17, 182-197. [CrossRef] [PubMed]

20. Billiet, T.; Vandenhaute, M. A review of trends and limitations in hydrogel-rapid prototyping for tissue engineering. Biomaterials 2012, 33, 6020-6041. [CrossRef]

21. Wong, K.V.; Hernandez, A. A review of additive manufacturing. ISRN Mech. Eng. 2012, 1-10. [CrossRef]

22. Castilho, M.D.; Malda, J.; Levato, R. Bio-resin for high resolution lithography-based biofabrication of complex cell-laden constructs. Biofabrication 2018, 10, 034101.

23. Carve, M.; Wlodkowic, D. 3D-Printed Chips: Compatibility of Additive Manufacturing Photopolymeric Substrata with Biological Applications. Micromachines 2018, 9, 91. [CrossRef] [PubMed]

24. Yap, C.Y. Review of selective laser melting: Materials and applications. Appl. Phys. Rev. 2015, 2, 041101. [CrossRef]

25. Rahman, Z.; Barakh Ali, S.F.; Ozkan, T.; Charoo, N.A.; Reddy, I.K.; Khan, M.A. Additive Manufacturing with 3D Printing: Progress from Bench to Bedside. AAPS J. 2018, 20, 101. [CrossRef]

26. Do, A.V.; Khorsand, B. 3D printing of scaffolds for tissue regeneration applications. Adv. Healthc. Mater. 2015, 4, 1742-1762. [CrossRef] [PubMed]

27. Boland, T.; Tao, X.; Damon, B.J.; Manley, B.; Kesari, P.; Jalota, S.; Bhaduri, S. Drop-on-demand printing of cells and materials for designer tissue constructs. Mater. Sci. Eng. C 2006, 27, 372-376. [CrossRef]

28. Bohandy, J.; Kim, B.F. Metal deposition from a supported metal !lm using an excimer laser. J. Appl. Phys. 1986, 60, 1538-1539. [CrossRef]

29. Malda, J.; Visser, J.; Melchels, F.P.; Jüngst, T.; Hennink, W.E.; Dhert, W.J.; Groll, J.; Hutmacher, D.W. 25th anniversary article: Engineering hydrogels for biofabrication. Adv. Mater. 2013, 25, 5011-5028. [CrossRef]

30. Garcia, J.; Yang, Z.; Mongrain, R.; Leask, R.L.; Lachapelle, K. 3D printing materials and their use in medical education: A review of current technology and trends for the future. BMJ Simul. Technol. Enhanc. Learn. 2018, 4, 27-40. [CrossRef]

31. Chan, H.H.; Siewerdsen, J.H.; Vescan, A. 3D rapid prototyping for otolaryngology-head and neck surgery: Applications in image-guidance, surgical simulation and patient-specific modeling. PLoS ONE 2015, 10, e0136370. [CrossRef] [PubMed]

32. Ripley, B.; Kelil, T.; Cheezum, M.K. 3D printing based on cardiac CT assists anatomic visualization prior to transcatheter aortic valve replacement. J. Cardiovasc. Comput. Tomogr. 2016, 10, 28-36. [CrossRef]

33. Emmott, A.; Garcia, J.; Chung, J. Biomechanics of the ascending thoracic aorta: A clinical perspective on engineering data. Can. J. Cardiol. 2016, 32, 35-47. [CrossRef] [PubMed]

34. Lewis, J.A. Direct ink writing of 3D functional materials. Adv. Funct. Mater. 2006, 16, 2193-2204. [CrossRef] 
35. Bramlet, M.; Olivieri, L.; Farooqi, K. Impact of three-dimensional printing on the study and treatment of congenital heart disease. Circ. Res. 2017, 120, 904-907. [CrossRef] [PubMed]

36. Ngoa, T.D.; Kashania, A.; Imbalzanoa, G.; Nguyena, K.T.Q.; Huib, D. Additive manufacturing (3D printing): A review of materials, methods, applications and challenges. Compos. B Eng. 2018, 143, 172-196. [CrossRef]

37. Tack, P.; Victor, J. 3D-printing techniques in a medical setting: A systematic literature review. Biomed. Eng. Online 2016, 15, 115. [CrossRef]

38. Sun, Z.; Lau, I.; Wong, Y.H.; Yeong, C.H. Personalized Three-Dimensional Printed Models in Congenital Heart Disease. J. Clin. Med. 2019, 8, 522. [CrossRef]

39. Batteux, C. 3D-Printed Models for Surgical Planning in Complex Congenital Heart Diseases: A Systematic Review. Front. Pediatrics 2019, 7, 23. [CrossRef]

40. Padalino, M.A.; Basso, C. Surgically treated primary cardiac tumors in early infancy and childhood. J. Thorac. Cardiovasc. Surg. 2005, 129, 1358-1363. [CrossRef]

41. Schmauss, D.; Schmitz, C. Three-dimensional printing of models for preoperative planning and simulation of transcatheter valve replacement. Ann. Thorac. Surg. 2012, 93, e31-e33. [CrossRef] [PubMed]

42. Sodian, R.; Weber, S. Pediatriccardiac transplantation: Three-dimensional printing of anatomic models for surgical planning of heart transplantation in patients with univentricular heart. J. Thorac. Cardiovasc. Surg. 2008, 136, 1098-1099. [CrossRef]

43. Bateman, M.; William, L. Cardiac patient-specific three-dimensional models as surgical planning tools. Surgery 2020, 167, 259-263 [CrossRef] [PubMed]

44. Meier, L.M.; Meineri, M. Structural and congenital heart disease interventions: The role of three-dimensional printing. Neth. Heart J. 2017, 25, e65-e75. [CrossRef] [PubMed]

45. Hazeveld, A.; Slater, H.J.J.R.; Ren, Y. Accuracy and reproducibility of dental replica models reconstructed by different rapid prototyping techniques. Am. J. Orthod. Dentofac. Orthop. 2014, 145, 108-115. [CrossRef] [PubMed]

46. Shiraishi, I.; Yamagishi, M. Simulative operation on congenital heart disease using rubber- like urethane stereolithographic biomodels based on 3D datasets of multislice computed tomography. Eur. J. Cardiothorac. Surg. 2010, 37, 302-306. [CrossRef] [PubMed]

47. Yoo, S.J.; Van Arsdell, G.S. 3D printing in surgical management of double outlet right ventricle. Front. Pediatr. 2018, 5, 289. [CrossRef]

48. Motwani, M.; Burley, O.; Luckie, M.; Cunnington, C.; Pisaniello, A.D.; Hasan, R.; Malik, I.; Fraser, D.G. 3D-printing assisted closure of paravalvular leak. J. Cardiovasc. Comput. Tomogr. 2020, 14, e66-e68. [CrossRef]

49. Engelhardt, S.; Sauerzapf, S.; Preim, B.; Karck, M.; Wolf, I.; De Simone, R. Flexible and comprehensive patient-specific mitral valve silicone models with chordae tendineae made from 3D-printable molds. Int. J. Comput. Assist. Radiol. Surg. 2019, 14, 1177-1186. [CrossRef] [PubMed]

50. Zopf, D.A.; Flanagan, C.L.; Wheeler, M.; Hollister, S.J.; Green, G.E. Treatment of severe porcine tracheomalacia with a 3dimensionally printed, bioresorbable, external airway splint. JAMA Otolaryngol. Head Neck Surg. 2014, 140, 66-71. [CrossRef]

51. Fan, Y.; Yang, F.; Cheung, G.S.; Chan, A.K.; Wang, D.D.; Lam, Y.Y.; Chow, M.C.; Leong, M.C.; Kam, K.K.; So, K.C.; et al. Device Sizing Guided by Echocardiography-Based Three-Dimensional Printing Is Associated with Superior Outcome after Percutaneous Left Atrial Appendage Occlusion. J. Am. Soc. Echocardiogr. 2019, 32, 708-719.e1. [CrossRef]

52. Lazkani, M.; Faran, B. Postinfarct VSD management using 3D computer printing assisted percutaneous closure. Indian Heart J. 2015, 67, 581-585. [CrossRef]

53. Kim, M.S.; Hansgen, A.R.; Carroll, J.D. Use of rapid prototyping in the care of patients with structural heart disease. Trends Cardiovasc. Med. 2008, 18, 210-216. [CrossRef]

54. Riesenkampff, E.; Rietdorf, U. The practical clinical value of three-dimensional models of complex congenitally mal- formed hearts. J. Thorac. Cardiovasc. Surg. 2009, 138, 571-580. [CrossRef]

55. Olivieri, L.J.; Krieger, A. Three-dimensional printing of intracardiac defects from three-dimensional echocardiographic images: Feasibility and relative accuracy. J. Am. Soc. Echocardiogr. 2015, 28, 392-397. [CrossRef]

56. Valverde, I.; Gomez, G. Three-dimensional patient-specific cardiac model for surgical planning in Nikaidoh procedure. Cardiol. Young. 2015, 25, 698-704. [CrossRef] [PubMed]

57. Rossi, L.; Penela, D.; Doni, L.; Marazzi, R.; Napoli, V.; Napoli, L. Development of simulation combining a physical heart model and three-dimensional system for electrophysiology training. Pacing Clin. Electrophysiol. 2018, 41, 1461-1466. [CrossRef] [PubMed]

58. Valverde, I.; Gomez, G. 3D-printed models for planning endovascular stenting in transverse aortic arch hypo-plasia. Catheter. Cardiovasc. Interv. 2015, 85, 1006-1012. [CrossRef]

59. Yeazel, T.R.; Becker, M.L. Advancing Towards 3D Printing of Bioresorbable Shape Memory Polymer Stents. Biomacromolecules 2020, 21, 3957-3965. [CrossRef]

60. Modi, B.N.; Ryan, M.; Chattersingh, A. Optimal Application of Fractional Flow Reserve to Assess Serial Coronary Artery Disease: A 3D-Printed Experimental Study with Clinical Validation. J. Am. Heart Assoc. 2018, 7, e010279. [CrossRef] [PubMed]

61. Oliveira-Santos, M.; Oliveira-Santos, E.; Marinho, A.V.; Leite, L.; Guardado, J.; Matos, V.; Pego, G.M.; Marques, J.S. Patient-specific 3D printing simulation to guide complex coronary intervention. Rev. Port. Cardiol. 2018, 37, 541.e1-541.e4. [CrossRef]

62. Wang, H.; Liu, J.; Zheng, X. Three-dimensional virtual surgery models for percutaneous coronary intervention (PCI) optimization strategies. Sci. Rep. 2015, 5, 10945. [CrossRef] [PubMed] 
63. Velasco Forte, M.N.; Byrne, N.; Valverde Perez, I.; Bell, A.; Gómez-Ciriza, G.; Krasemann, T.; Sievert, H.; Simpson, J.; Pushparajah, K.; Razavi, R.; et al. 3D-printed models in patients with coronary artery fistulae: Anatomical assessment and interventional planning. Eurointervention 2017, 13, e1080-e1083. [CrossRef]

64. Sedaghat, A.; Wolpers, A.C. Percutaneous treatment of a saccular coronary artery aneurysm using multimodal imaging and rapid prototyping. Eur. Heart J. 2018, 39, 4125. [CrossRef]

65. Mohamed, E.; Telila, T.; Osaki, S.; Jacobson, K. Percutaneous closure of left ventricle pseudoaneurysm using 3D-printed heart model for procedure planning: A novel approach. Catheter. Cardiovasc. Interv. 2019, 94, 874-877. [CrossRef]

66. Bompotis, G.; Meletidou, M.; Karakanas, A.; Sotiriou, S.; Sachpekidis, V.; Konstantinidou, M.; Lazaridis, I. Transcatheter Aortic Valve Implantation using 3-D printing modeling assistance. A single center experience. Hell. J. Cardiol. 2020, 61, 131-132. [CrossRef]

67. Baribeau, Y.; Sharkey, A.; Mahmood, E.; Feng, R.; Chaudhary, O.; Baribeau, V.; Khabbaz, K. Three-Dimensional Printing and Transesophageal Echocardiographic Imaging of Patient-Specific Mitral Valve Models in a Pulsatile Phantom Model. J. Cardiothorac. Vasc. Anesth. 2019, 33, 3469-3475. [CrossRef] [PubMed]

68. Iriart, X.; Ciobotaru, V.; Martin, C.; Cochet, H.; Jalal, Z.; Thambo, J.-B.; Quessard, A. Role of cardiac imaging and three-dimensional printing in percutaneous appendage closure. Arch. Cardiovasc. Dis. 2018, 111, 411-420. [CrossRef] [PubMed]

69. Lodziński, P.; Balsam, P.; Peller, M. Three-dimensional print facilitated ventricular tachycardia ablation in patient with corrected congenital heart disease. Cardiol. J. 2017, 24, 584-585. [CrossRef]

70. Randles, A.; Frakes, D.H.; Leopold, J.A. Computational Fluid Dynamics and Additive Manufacturing to Diagnose and Treat. Cardiovascular Disease. Trends Biotechnol. 2017, 35, 1049-1061. [CrossRef]

71. De Zélicourt, D.; Pekkan, K.; Kitajima, H.; Frakes, D.; Yoganathan, A.P. Single-step stereolithography of complex anatomical models for optical flow measurements. J. Biomech. Eng. 2005, 127, 204-207. [CrossRef]

72. Taylor, C.A.; Fonte, T.A. Computational Fluid Dynamics Applied to Cardiac Computed Tomography for Noninvasive Quantification of Fractional Flow Reserve. J. Am. Coll. Cardiol. 2013, 61, 2233-2241. [CrossRef]

73. Esses, S.J.; Berman, P. Clinical applications of physical 3D models derived from MDCT data and created by rapid prototyping. AJR Am. J. Roentgenol. 2011, 196, W683-W688. [CrossRef]

74. Maragiannis, D.; Jackson, M.S. Replicating Patient-Specific Severe Aortic Valve Stenosis With Functional 3D Modeling. Circ. Cardiovasc. Imaging 2015, 8, e003626. [CrossRef]

75. Qian, Z.; Wang, K. Quantitative Prediction of Paravalvular Leak in Transcatheter Aortic Valve Replacement Based on TissueMimicking 3D Printing. JACC Cardiovasc. Imaging 2017, 10, 719-731. [CrossRef]

76. Gross, B.C.; Erkal, J.L.; Lockwood, S.Y.; Chen, C.; Spence, D.M. Evaluation of 3D printing and its potential impact on biotechnology and the chemical sciences. Anal. Chem. 2014, 86, 3240-3253. [CrossRef] [PubMed]

77. Ozbolat, I.T.; Yu, Y. Bioprinting toward organ fabrication: Challenges and future trends. IEEE Trans. Biomed. Eng. 2013, 60, 691-699. [CrossRef] [PubMed]

78. Mahrholdt, H.; Wagner, A. Delayed enhancement cardiovascular magnetic resonance assessment of non-ischaemic cardiomyopathies. Eur. Heart J. 2005, 26, 1461-1474. [CrossRef]

79. Liao, J.; Huang, W.; Liu, G. Animal models of coronary heart disease. J. Biomed. Res. 2016, 30, 3-10. [CrossRef]

80. Tanimoto, A.; Kawaguchi, H. Microminipig, a non-rodent experimental animal optimized for life science research: Novel atherosclerosis model induced by high fat and cholesterol diet. J. Pharmacol. Sci. 2011, 115, 115-121.

81. Beg, S.; Almalki, W.H. 3D printing for drug delivery and biomedical applications. Drug Discov. Today 2020, $25,1668-1681$. [CrossRef] [PubMed]

82. Gear, J.; Craig, S. Radioactive 3D printing for the production of molecular imaging phantoms. Phys. Med. Biol. 2020, 65, 17. [CrossRef] [PubMed]

83. Cui, X.; Boland, T. Thermal inkjet printing in tissue engineering and regenerative medicine. Recent Pat. Drug Deliv. Formul. 2012, 6, 149-155. [CrossRef]

84. Murphy, S.V.; Atala, A. 3D bioprinting of tissues and organs. Nat. Biotechnol. 2014, 32, 773-785. [CrossRef]

85. Gorenek, B.; Blomström, C. Cardiac arrhythmias in acute coronary syndromes: Position paper from the joint EHRA, ACCA, and EAPCI task force. EP Eur. 2014, 16, 1655-1673. [CrossRef]

86. Henkel, D.M.; Witt, B.J. Ventricular arrhythmias after acute myocardial infarction: A 20-year community study. Am. Heart J. 2006, 151, 806-812. [CrossRef] [PubMed]

87. Shin, S.R.; Jung, S.M. Carbon-Nanotube-Embedded Hydrogel Sheets for Engineering Cardiac Constructs and Bioactuators. ACS Nano 2013, 7, 2369-2380. [CrossRef]

88. Basara, G.; Saeidi-Javash, M. Electrically conductive 3D-printed Ti3C2Tx MXene-PEG composite constructs for cardiac tissue engineering. Acta Biomater. 2020, S1742-S7061, 30747-30749. [CrossRef]

89. Izadifar, M.; Chapman, D. UV-Assisted 3D Bioprinting of Nanoreinforced Hybrid Cardiac Patch for Myocardial Tissue Engineering. Tissue Eng. Part C Methods 2018, 24, 74-88. [CrossRef] [PubMed]

90. Vermeulen, N.; Haddow, G.; Seymour, T.; Faulkner-Jones, A.; Shu, W. 3D bioprint me: A socioethical view of bioprinting human organs and tissues. J. Med. Ethics. 2017, 43, 618-624. [CrossRef]

91. Yeung, E.; Fukunishi, T. Cardiac regeneration using human-induced pluripotent stem cell-derived biomaterial-free 3D-bioprinted cardiac patch in vivo. J. Tissue Eng. Regen. Med. 2019, 13, 2031-2039. [CrossRef] [PubMed] 
92. Gaetani, R.; Feyen, D.A. Epicardial application of cardiac progenitor cells in a 3D-printed gelatin/hyaluronic acid patch preserves cardiac function after myocardial infarction. Biomaterials 2015, 61, 339-348. [CrossRef]

93. Jang, J.; Park, H.J. 3D-printed complex tissue construct using stem cell-laden decellularized extracellular matrix bioinks for cardiac repair. Biomaterials 2017, 112, 264-274. [CrossRef]

94. Gao, L.; Kupfer, M.E. Myocardial Tissue Engineering with Cells Derived From Human-Induced Pluripotent Stem Cells and a Native-Like, High-Resolution, 3-Dimensionally Printed Scaffold. Circ. Res. 2017, 120, 1318-1325. [CrossRef]

95. Wang, Z.; Lee, S.J. 3D bioprinted functional and contractile cardiac tissue constructs. Acta Biomater. 2018, 70, 48-56. [CrossRef] [PubMed]

96. Su, P.; Sang, J.L. In vivo evaluation and characterization of a bio-absorbable drug-coated stent fabricated using a 3D-printing system. Mater. Lett. 2015, 141, 355-358. [CrossRef]

97. Ventola, C.L. Medical Applications for 3D Printing: Current and Projected Uses. PT Peer-Rev. J. Formul. Manag. 2014, 39, 704-711.

98. Hoy, M.B. 3D printing: Making things at the library. Med. Ref. Serv. Q 2013, 32, 94-99. [CrossRef] 